\title{
Neoparamoeba perurans is a cosmopolitan aetiological agent of amoebic gill disease
}

\author{
Neil D. Young ${ }^{1, *}$, Iva Dyková ${ }^{2}$, Kevin Snekvik ${ }^{3}$, Barbara F. Nowak ${ }^{1}$, \\ Richard N. Morrison ${ }^{1}$
}

\begin{abstract}
${ }^{1}$ School of Aquaculture, Tasmanian Aquaculture and Fisheries Institute, University of Tasmania and Aquafin CRC, Locked Bag 1370, Launceston, Tasmania 7250, Australia

${ }^{2}$ Institute of Parasitology, Academy of Sciences of the Czech Republic, České Budějovice, Czech Republic

${ }^{3}$ Washington Animal Disease Diagnostic Laboratory and Department of Veterinary Microbiology and Pathology, College of Veterinary Medicine, Washington State University, Pullman, Washington 99164-7034, USA
\end{abstract}

\begin{abstract}
Previously we described a new member of the Neoparamoeba genus, N. perurans, and showed that it is an agent of amoebic gill disease (AGD) of Atlantic salmon Salmo salar cultured in southeast Tasmania, Australia. Given the broad distribution of cases of AGD, we were interested in extending our studies to epizootics in farmed fish from other sites around the world. Oligonucleotide probes that hybridise with the $18 \mathrm{~S}$ rRNA of $N$. perurans, $N$. branchiphila or $N$. pemaquidensis were used to examine archival samples of AGD in Tasmania as well as samples obtained from 4 host fish species cultured across 6 countries. In archival samples, $N$. perurans was the only detectable amoeba, confirming that it has been the predominant aetiological agent of AGD in Tasmania since epizootics were first reported. $N$. perurans was also the exclusive agent of AGD in 4 host species across 6 countries. Together, these data show that $N$. perurans is a cosmopolitan agent of AGD and, therefore, of significance to the global mariculture industry.
\end{abstract}

KEY WORDS: Amoebic gill disease · Neoparamoeba perurans · In situ hybridisation · Aquaculture Resale or republication not permitted without written consent of the publisher

\section{INTRODUCTION}

Amoebic gill disease (AGD) is an ectoparasitic condition of some farm-reared marine fish (Munday 1986, Kent et al. 1988, Dyková et al. 1995). The first AGD epizootic was reported by Munday (1986) and affected both rainbow trout Oncorhynchus mykiss and Atlantic salmon Salmo salar cultured in southeast Tasmania, Australia. At that time the pathogen was not identified, but later, by means of morphological evidence, the aetiological agent was described as Paramoeba sp. (Roubal et al. 1989). In the interim, Kent et al. (1988) described $P$. pemaquidensis (now Neoparamoeba pemaquidensis) as the agent of AGD of coho salmon $O$. kisutch farmed in the state of Washington, USA.

Many authors assumed that Neoparamoeba pemaquidensis was the sole aetiological agent of AGD of Atlantic salmon (Douglas-Helders et al. 2000, 2001a,b,
2002, 2003a,b,c, 2005, Adams \& Nowak 2001, Munday et al. 2001, Tan et al. 2002, Clark et al. 2003, Powell \& Clark 2003, 2004, Bowman \& Nowak 2004, Wong et al. 2004, Zilberg 2005). However, the isolation of $N$. branchiphila from the gills of AGD-affected fish (Dyková et al. 2005) suggested that AGD may be a condition of mixed aetiology. While $N$. pemaquidensis and $N$. branchiphila were the predominant species of amoebae cultured from the gills of AGD-affected fish, neither have been shown to induce AGD in fish that were experimentally inoculated with clonal cultured strains (Kent et al. 1988, Howard \& Carson 1993a, Morrison et al. 2005, Vincent et al. 2007). Recently, Young et al. (2007) discovered N. perurans and showed it to be an agent of AGD in Atlantic salmon cultured in southeast Tasmania. In this instance, neither $N$. pemaquidensis nor $N$. branchiphila were detected in sections of gill tissue affected by AGD. In 
cases of AGD reported elsewhere, it is not known what role $N$. perurans, $N$. pemaquidensis and/or $N$. branchiphila play. Therefore, our objective was to use species-specific molecular probes to determine the aetiological agent or agents of AGD in 4 host species in 6 countries.

\section{MATERIALS AND METHODS}

Paraffin-embedded gill tissues were obtained from 4 fish species predominantly during or following epizootics at commercial fish farming operations in 6 countries (Table 1). An epizootic was not reported from Chinook salmon Oncorhynchus tshawytscha cultured in New Zealand; however, the smallest fish (runts) within the healthy population were observed to have gill lesions that corresponded with AGD and these fish were used in this study. Gill tissues were sectioned (3 to $7 \mu \mathrm{m})$, stained with haematoxylin and eosin (H\&E) and examined with light microscopy. Alternatively, sections $(7 \mu \mathrm{m})$ of gill tissues were placed onto Polysine glass slides (Menzel-Gläser) and dried overnight at $37^{\circ} \mathrm{C}$. Sections were hybridised with a digoxigenin (DIG)-labelled 'universal' 18S rRNA oligonucleotide probe to verify the integrity of rRNA as previously described (Young et al. 2007). All gill tissues with suitable host and amoeba rRNA were serially sectioned, placed onto Polysine glass slides and incubated with Neoparamoeba perurans, $N$. branchiphila and $N$. pemaquidensis DIG-labelled oligonucleotide probes as previously described (Young et al. 2007). Positive and negative (no probe) controls were run in parallel with each in situ hybridisation experiment by hybridising each probe with a section containing representative strains of each Neoparamoeba species termed an 'amoebae array' as previously described (Young et al. 2007). Tissue sections were incubated for up to $1 \mathrm{~h}$ with in a premixed solution of 5-bromo-4-chloro-3-indolyl phosphate and nitro blue tetrazolium (BCIP/NBT) (Sigma-Aldrich) for colour development. The hybridisation procedure for the gill tissue sections from AGD-affected turbot Scophthalmus maximus (= Psetta maxima) was modified as gill tissue was provided presectioned $(5 \mu \mathrm{m})$ on non-coated slides. Preliminary hybridisation experiments with these sections resulted in tissues detaching from the slides. Therefore, the prehybridisation procedure was limited to dewaxing, rehydration and sequential washes of sections for $2 \times$ 5 min with diethyl pyrocarbonate-treated phosphate buffered saline (PBS) at room temperature. Sections were then directly probed with $N$. perurans, $N$. branchiphila and $N$. pemaquidensis oligonucleotides as previously described (Young et al. 2007). Positive and no-probe controls were included with each in situ hybridisation experiment as described previously. An extended incubation (18 h) with premixed BCIP/NBT solution was required for colour development.

\section{RESULTS AND DISCUSSION}

When Dyková et al. (2000) described several strains of Neoparamoeba from AGD- affected European bass Dicentrarchus labrax and turbot, the authors suggested that the agents of AGD should only be assigned to Neoparamoeba, since members of the genus, N. pemaquidensis and N. aestuarina, were morphologically identical. Since then, another morphologically indistinct species, N. branchiphila, from the same genus was cultured from AGDaffected fish (Dyková et al. 2005) and, therefore, up

Table 1. Gill tissue samples obtained from farm-reared populations of fish with presumptive cases of amoebic gill disease. Year: year gill tissues were originally sampled. n: number of fish sampled at each time point. Fixative used to prepare gill tissues for histology: seawater Davidson's fixative (SWD), 10\% formalin prepared in seawater (SWF) or 10\% neutral buffered formalin (NBF)

\begin{tabular}{|c|c|c|c|c|}
\hline Species & Location & Year & $\mathrm{n}$ & Fixative \\
\hline \multirow[t]{7}{*}{ Atlantic salmon } & Bruny Island, southeast Tasmania, Australia ${ }^{a}$ & 1987 & 1 & SWD \\
\hline & Brabazon Point, southeast Tasmania, Australia ${ }^{a}$ & 1987 & 1 & SWD \\
\hline & \multirow[t]{2}{*}{ Tamar River, north Tasmania, Australia ${ }^{\mathrm{a}}$} & 2006 & 3 & NBF \\
\hline & & 2007 & 1 & SWD \\
\hline & Galway, Ireland & 2004 & 3 & NBF \\
\hline & Puget Sound, Washington, USA & 2006 & 3 & NBF \\
\hline & North Uist, Western Isles, Scotland, UK & 2006 & 4 & SWF \\
\hline Rainbow trout & Recherche Bay, southeast Tasmania, Australia ${ }^{a}$ & 1988 & 1 & SWD \\
\hline Chinook salmon & Picton, Queen Charlotte Sound, New Zealand & 2006 & 3 & NBF \\
\hline Turbot & Northwest Spain & 2001 & 1 & SWD \\
\hline
\end{tabular}


to 3 Neoparamoeba species were potential aetiological agents of AGD. Recently, we described a new species, N. perurans, and showed that it is an agent of AGD in Atlantic salmon from southeast Tasmania (Young et al. 2007). This resolved AGD aetiology in recent cases of AGD in Atlantic salmon cultured in southeast Tasmania, but not in historical cases of AGD from southeast Tasmania, nor in cases described elsewhere.

In this study, cases of AGD were verified by histological examination (Dyková \& Novoa 2001). All histological sections revealed structural changes consistent with the pathology described in cases of AGD (Kent et al. 1988, Roubal et al. 1989, Munday et al. 1990,
Dyková et al. 1995, Rodger \& McArdle 1996). The most significant change was the development of gill lesions due to the hyperplasia of epithelial-like cells (Figs. 1, 2 $\& 3)$. This resulted in extensive secondary lamellar fusion and the formation of interlamellar vesicles (Figs. 2 \& 3). Amoebae were located between the secondary lamellae or at the distal ends of fused lamellae (Figs. 1, $2 \& 3$ ). The presence of a perinuclear eosinophilic body was representative of the endosymbiotic Perkinsiella amoebae-like organism (PLO) (Dyková et al. 2003) (Fig. 1) and was identified in amoebae in all sections examined.

Retrospective studies applying in situ hybridisation probes to tissue samples have been used to determine

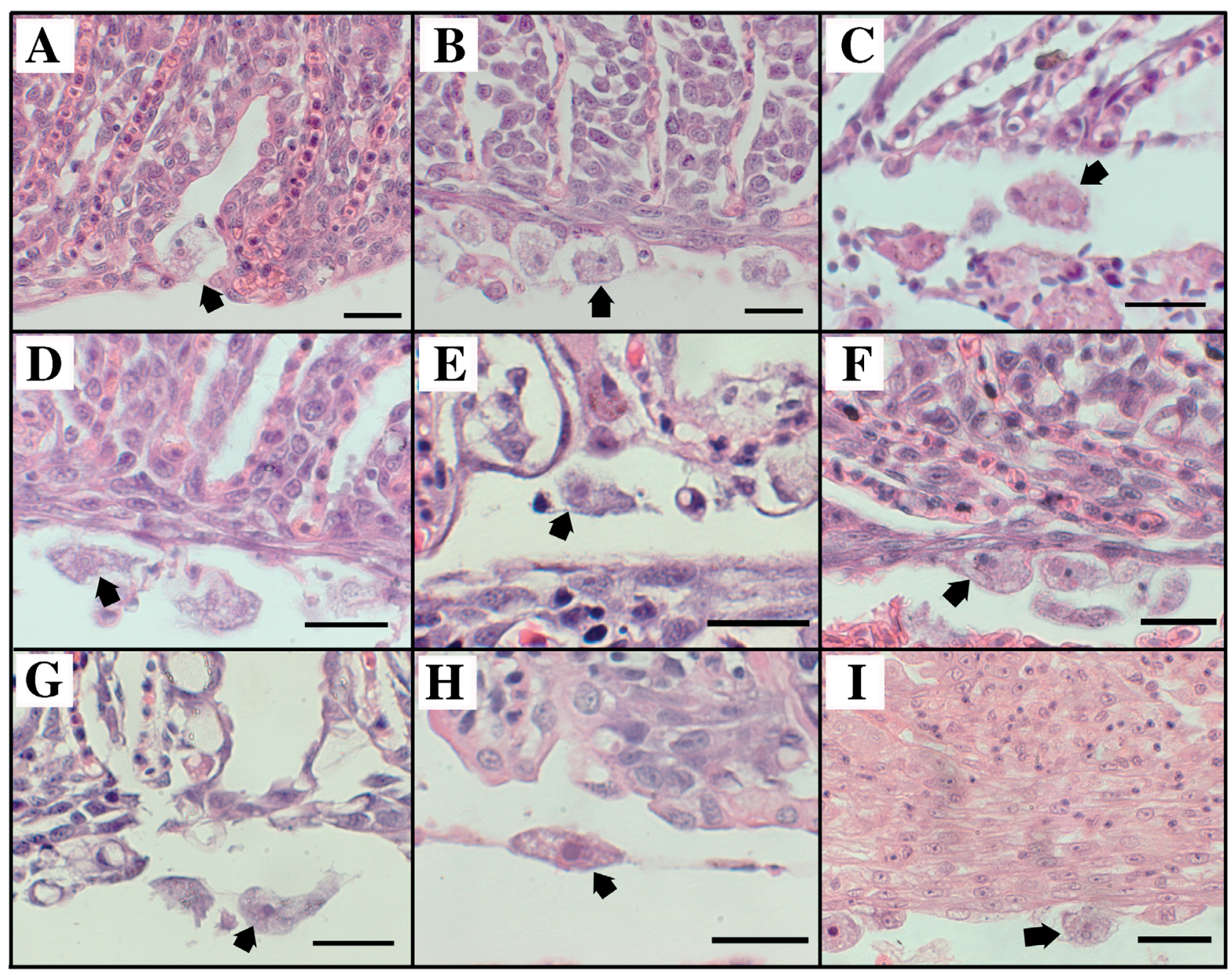

Fig. 1. Confirmation of the presence of amoebae (arrows) containing endosymbiotic Perkinsiella amoebae-like organisms in H\&E stained, 3 to $7 \mu \mathrm{m}$ thick sections from fish examined in this study. Images are representative of the pathology observed in specimens from each species and location. (A) Atlantic salmon, Tamar River, north Tasmania, Australia $(\mathrm{n}=4)$. (B) Atlantic salmon, Bruny Island, southeast Tasmania, Australia, 1987 ( $\mathrm{n}=1$ ). (C) Atlantic salmon, Brabazon Point, southeast Tasmania, Australia, 1987 ( $\mathrm{n}=1$ ). (D) Rainbow trout, Recherche Bay, southeast Tasmania, Australia, $1988(\mathrm{n}=1)$. (E) Atlantic salmon, Galway, Ireland $(\mathrm{n}=3)$. (F) Atlantic salmon, Western Isles, Scotland, UK $(\mathrm{n}=4) .(\mathrm{G})$ Atlantic salmon, Washington, USA $(\mathrm{n}=3)$. $(\mathrm{H})$ Rainbow trout, Picton, New Zealand $(n=3)$. (I) Turbot, northwest Spain $(n=1)$. Scale bars $=25 \mu \mathrm{m}$ 


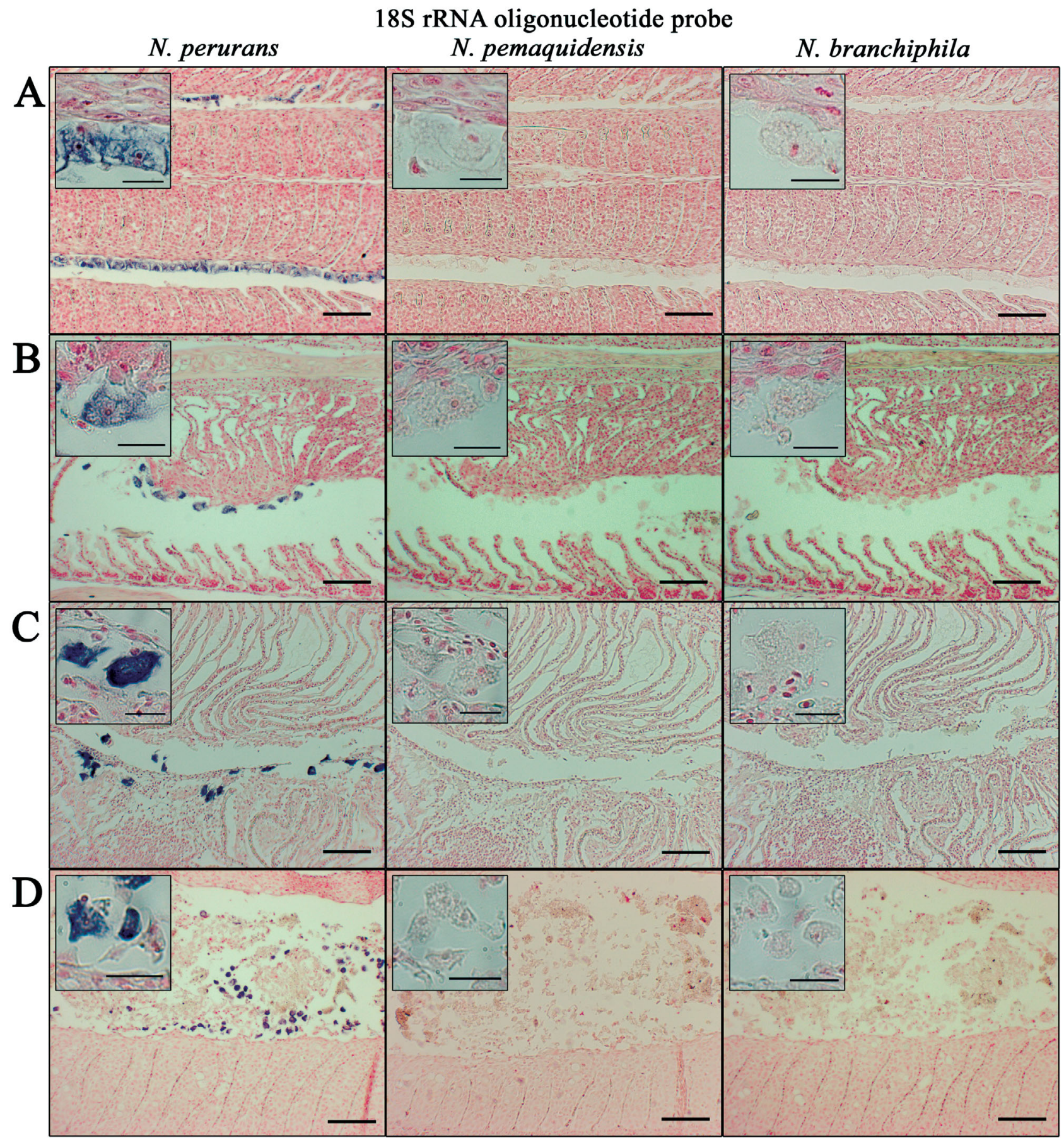

Fig. 2. Results of in situ hybridisation experiments based on species-specific probes that hybridise to the 18S rRNA of either Neoparamoeba perurans, N. pemaquidensis or N. branchiphila in gill samples from fish cultured in Australia. Images are representative of the pathology observed in specimens from each species and location. (A) Atlantic salmon, Bruny Island, southeast Tasmania, 1987 ( $\mathrm{n}=1$ ). (B) Atlantic salmon, Brabazon Point, southeast Tasmania, 1987 ( $\mathrm{n}=1$ ). (C) Rainbow trout, Recherche Bay, southeast Tasmania, $1988(\mathrm{n}=1)$. (D) Atlantic salmon, Tamar River, north Tasmania, $2006(\mathrm{n}=4)$. Probe positive and probe negative amoebae are magnified within the insets. Scale bars $=100 \mu \mathrm{m}$ (main image) or $20 \mu \mathrm{m}$ (inset)

the aetiological agents of disease and the geographical and temporal distribution of marine diseases (Hasson et al. 1999, Friedman et al. 2005, Yee et al. 2005). In this study, archival tissues from cultured Atlantic salmon and rainbow trout in southeast Tasmania, Australia, were probed for Neoparamoeba perurans, N. bran- 


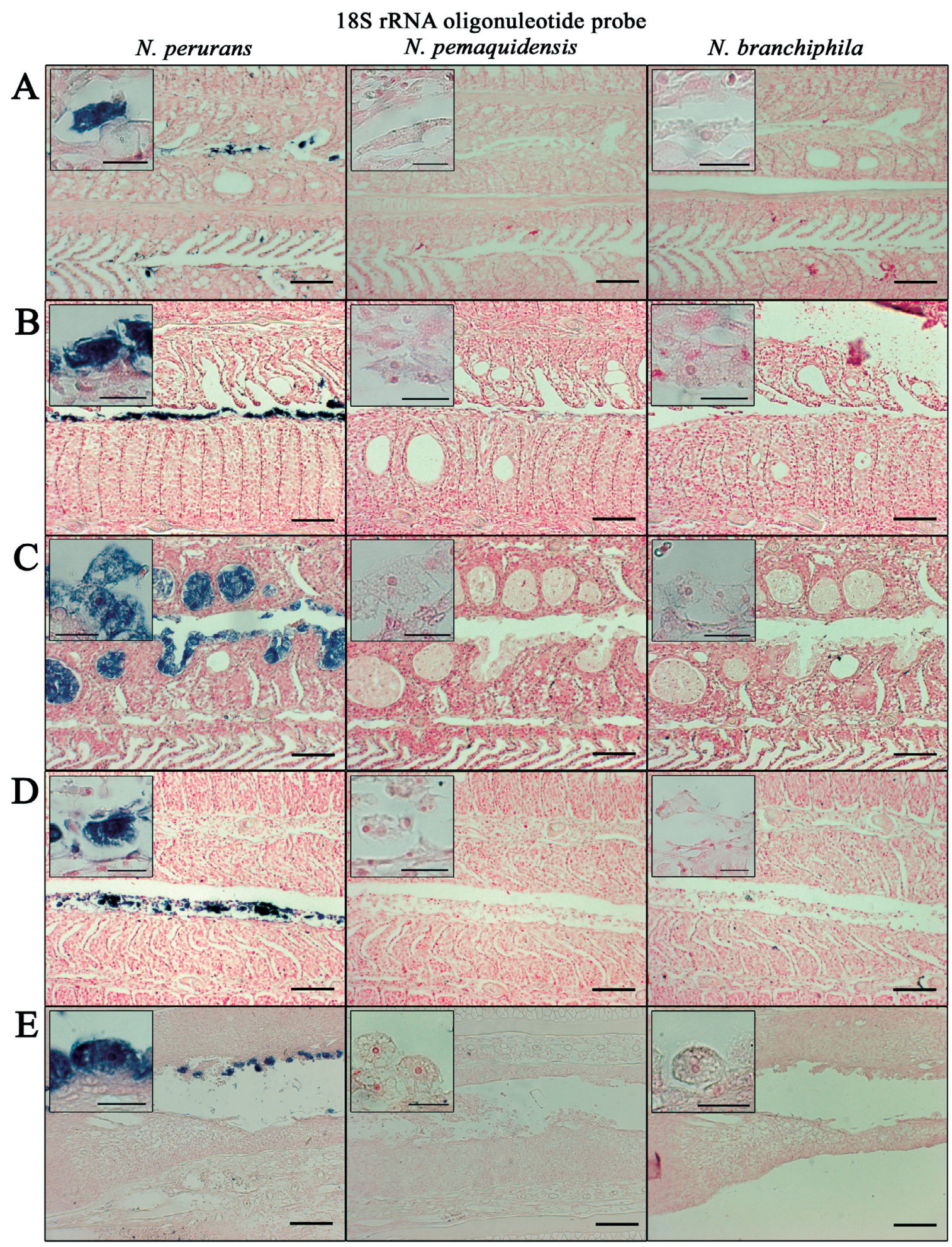

Fig. 3. Results of in situ hybridisation experiments based on species-specific probes that hybridise to the 18S rRNA of either Neoparamoeba perurans, $N$. pemaquidensis or $N$. branchiphila in gill samples from fish sampled worldwide. Images are representative of the pathology observed in specimens from each species and location. (A) Chinook salmon, Picton, New Zealand $(\mathrm{n}=3)$. (B) Atlantic salmon, Galway, Ireland $(\mathrm{n}=3)$. (C) Atlantic salmon, Western Isles, Scotland, UK $(\mathrm{n}=4)$. (D) Atlantic salmon, Washington, USA $(n=3)$. (E) Turbot, northwest Spain $(n=1)$. Images are representative of in situ hybridisation experiments using 1 to 4 amoebic gill disease (AGD)-affected fish from each location (see Table 1). Probe positive and probe negative amoebae are magnified within the insets. Scale bars $=100 \mu \mathrm{m}$ (main image) or $20 \mu \mathrm{m}$ (inset) 
chiphila and $N$. pemaquidensis. These samples were obtained in 1987 and 1988, coinciding with the first confirmed records of AGD epizootics (Munday 1986, Roubal et al. 1989). In southeast Tasmania, recurrent AGD epizootics occur (Roubal et al. 1989, Munday et al. 1990, 1993) and fish are repeatedly treated sometimes more often than monthly during summer. Therefore, we sought to clarify whether there was temporal change in Neoparamoeba species associated with AGD in southeast Tasmania. The $N$. perurans specific probe hybridised with all trophozoites in all sections examined (Fig. 2A-C) consistent with samples obtained in recent cases of AGD in this region (Young et al. 2007). In serially sectioned gill tissues neither the $N$. pemaquidensis nor the $N$. branchiphila specific probes hybridised with any trophozoites (Fig. 2A-C). Neoparamoeba species-specific probes hybridised with the corresponding Neoparamoeba species on the amoebae array while no signal was detected in trophozoites on the amoebae array when the probes were omitted from the hybridisation procedure. This occurred in all hybridisation experiments. In northern Tasmania, there is a single Atlantic salmon farm located on the Tamar River. During the 2006-07 summer, an AGD epizootic occurred, and in all samples obtained from affected fish $N$. perurans was the only detectable amoeba (Fig. 2D). Together, these data suggest that $N$. perurans has been and remains the predominant aetiological agent of AGD throughout Tasmania.

There have been numerous published and unpublished reports of AGD in cultured fish (Nowak et al. 2002). Several hosts are susceptible and there is a worldwide distribution of cases (see review by Munday et al. 2001). Many salmonids are susceptible to AGD, and in this analysis, cases of AGD in Atlantic salmon, rainbow trout and Chinook salmon were verified and the sole agent confirmed as $N$. perurans (Figs. $2 \& 3$ ). The locations of these cases were Tasmania (Atlantic salmon and rainbow trout), Galway, Ireland (Atlantic salmon) and Washington (Atlantic salmon). In addition, the first formal case of AGD in Atlantic salmon from Scotland, $\mathrm{UK}_{\text {, is presented }}$ together with a case of AGD in runt Chinook salmon from New Zealand, confirming the observations of AGD-like gill lesions in fish from this location (Munday et al. 1990, Howard \& Carson 1993b). Other than salmonids, AGD also affects turbot (Dyková et al. 1995, 1998) and the agent in 1 case from northwest Spain is confirmed here as $N$. perurans. Some background signal was detected in sections of turbot gill tissue. This was due to the extended colour development (18 h) that resulted in a non-specific pale blue colouration of cartilaginous tissues. These tissues were not associated with primary or secondary gill lamellae or trophozoites (data not shown).
In summary, we used a molecular-based procedure to probe histological sections obtained from 4 host fish species cultured across 6 countries. In all 21 specimens, N. perurans was the only species of Neoparamoeba shown to elicit AGD, confirming that this species is a cosmopolitan protozoan parasite of the temperate marine fish examined. Confirmation of $N$. perurans in regions of significant finfish production indicates that AGD is of global significance to the mariculture industry.

Acknowledgements. This work formed part of a project of Aquafin CRC and received funds from the Australian Government's CRCs Program, the Fisheries R \& D Corporation, other Aquafin CRC participants, ARC/NHMRC Research Network for Parasitology and the Czech Science Foundation (206/05/2384). We appreciate the support of Van Diemen Aquaculture in the provision of samples, in particular M. Hortle. We thank Dr. J. Carson, Dr. S. Pyecroft, Dr. J. Handlinger and A. Porteus (Fish Health Unit, DPIW) for the archival gill tissues from Tasmania. We thank Dr. H. Rodger for gill samples from Ireland. We are grateful to G. Lovell, A. Brown and B. Wybourne (The New Zealand King Salmon Company) for providing samples from New Zealand and Dr. D. Cox (Fish Vet Group) for providing samples from Scotland. We also thank H. Safavi for her insightful discussions.

\section{LITERATURE CITED}

Adams MB, Nowak BF (2001) Distribution and structure of lesions in the gills of Atlantic salmon, Salmo salar L., affected with amoebic gill disease. J Fish Dis 24:535-542

Bowman JP, Nowak BF (2004) Salmonid gill bacteria and their relationship to amoebic gill disease. J Fish Dis 27:483-492

Clark G, Powell MD, Nowak BF (2003) Effects of commercial freshwater bathing on reinfection of Atlantic salmon, Salmo salar, with amoebic gill disease. Aquaculture 219: $1-4$

Douglas-Helders GM, Nowak BF, Zilberg D, Carson J (2000) Survival of Paramoeba pemaquidensis on dead salmon: implications for management of cage hygiene. Bull Eur Assoc Fish Pathol 20:167-169

Douglas-Helders GM, Carson J, Howard T, Nowak BF (2001a) Development and validation of a new dot blot test for the detection of Paramoeba pemaquidensis (Page) in fish. J Fish Dis 24:273-280

Douglas-Helders GM, Saksida S, Raverty S, Nowak BF (2001b) Temperature as a risk factor for outbreaks of amoebic gill disease in farmed Atlantic salmon (Salmo salar). Bull Eur Assoc Fish Pathol 21:114-116

Douglas-Helders GM, Dawson DR, Carson J, Nowak BF (2002) Wild fish are not a significant reservoir for Neoparamoeba pemaquidensis (Page, 1987). J Fish Dis 25: $569-574$

Douglas-Helders GM, Handlinger J, Carson J, Nowak BF (2003a) Assessment over time of the infectivity of gill-derived and seawater dispersed Neoparamoeba pemaquidensis (Page, 1987). Bull Eur Assoc Fish Pathol 23:35-39

Douglas-Helders GM, O'Brien DP, McCorkell BE, Zilberg D, Gross A, Carson J, Nowak BF (2003b) Temporal and spatial distribution of paramoebae in the water column - a pilot study. J Fish Dis 26:231-240 
Douglas-Helders GM, Tan C, Carson J, Nowak BF (2003c) Effects of copper-based antifouling treatment on the presence of Neoparamoeba pemaquidensis Page, 1987 on nets and gills of reared Atlantic salmon (Salmo salar). Aquaculture 221:13-22

Douglas-Helders GM, Nowak BF, Butler R (2005) The effect of environmental factors on the distribution of Neoparamoeba pemaquidensis in Tasmania. J Fish Dis 28: 583-592

Dyková I, Novoa B (2001) Comments on diagnosis of amoebic gill disease (AGD) in turbot, Scophthalmus maximus. Bull Eur Assoc Fish Pathol 21:40-44

Dyková I, Figueras A, Novoa B (1995) Amoebic gill infection of turbot, Scophthalmus maximus. Folia Parasitol 42: 91-96

Dyková I, Figueras A, Novoa B, Casal JF (1998) Paramoeba sp., an agent of amoebic gill disease of turbot Scophthalmus maximus. Dis Aquat Org 33:137-141

Dyková I, Figueras A, Periç Z (2000) Neoparamoeba Page, 1987: light and electron microscopic observations on six strains of different origin. Dis Aquat Org 43:217-223

Dyková I, Fiala I, Lom J, Lukeš J (2003) Perkinsiella amoebae-like endosymbionts of Neoparamoeba spp., relatives of the kinetoplastid Ichthyobodo. Eur J Protistol 39:37-52

Dyková I, Nowak BF, Crosbie PBB, Fiala I and others (2005) Neoparamoeba branchiphila n. sp., and related species of the genus Neoparamoeba Page, 1987: morphological and molecular characterization of selected strains. J Fish Dis 28:49-64

Friedman CS, Brown HM, Ewing TW, Griffin FJ, Cherr GN (2005) Pilot study of the Olympia oyster Ostrea conchaphila in the San Francisco Bay estuary: description and distribution of diseases. Dis Aquat Org 65:1-8

Hasson KW, Lightner DV, Mari J, Bonami JR and others (1999) The geographic distribution of Taura Syndrome Virus (TSV) in the Americas: determination by histopathology and in situ hybridization using TSV-specific cDNA probes. Aquaculture 171:13-26

Howard T, Carson J (1993a) Progress report: development of a model of infection for amoebic gill disease. In: Papers presented at SALTAS 1993 research and development review seminar. Salmon Enterprises of Tasmania. Dover, Tasmania, p 103-111

Howard T, Carson J (1993b) Verification that Paramoeba species are consistently associated with gill damage in fish affected with amoebic gill disease. In: Papers presented at SALTAS 1993 research and development review seminar. Salmon Enterprises of Tasmania, Dover, Tasmania, p 69-80

Kent ML, Sawyer TK, Hedrick RP (1988) Paramoeba pemaquidensis (Sarcomastigophora, Paramoebidae) infestation of the gills of coho salmon Oncorhynchus kisutch reared in sea water. Dis Aquat Org 5:163-169

Morrison RN, Crosbie PBB, Cook MT, Adams MB, Nowak BF (2005) Cultured gill-derived Neoparamoeba pemaquidensis fails to elicit amoebic gill disease (AGD) in Atlantic salmon Salmo salar. Dis Aquat Org 66:135-144
Munday BL (1986) Diseases of salmonids. In: Humphrey JD, Langdon JS (eds) Workshop on diseases of Australian fish and shellfish. Department of Agriculture and Rural Affairs, Benalla, Victoria, p 127-141

Munday BL, Foster C, Roubal FR, Lester RJG (1990) Paramoebic gill infection and associated pathology of Atlantic salmon, Salmo salar, and rainbow trout, Salmo gairdneri, in Tasmania. In: Perkins FO, Cheng TC (eds) Pathology in marine science. Academic Press, London, p 215-222

Munday BL, Lange K, Foster C, Lester RJG, Handlinger J (1993) Amoebic gill disease of sea-caged salmonids in Tasmanian waters. Tasman Fish Res 28:14-19

Munday BL, Zilberg D, Findlay V (2001) Gill disease of marine fish caused by infection with Neoparamoeba pemaquidensis. J Fish Dis 24:497-507

Nowak BF, Carson J, Powell MD, Dyková I (2002) Amoebic gill disease in the marine environment. Bull Eur Assoc Fish Pathol 22:144-147

Powell MD, Clark GA (2003) In vitro survival and the effect of water chemistry and oxidative chemical treatments on isolated gill amoebae from AGD-affected Atlantic salmon. Aquaculture 220:1-4

Powell MD, Clark GA (2004) Efficacy and toxicity of oxidative disinfectants for the removal of gill amoebae from the gills of amoebic gill disease affected Atlantic salmon (Salmo salar L.) in freshwater. Aquac Res 35:112-123

Rodger HD, McArdle JF (1996) An outbreak of amoebic gill disease in Ireland. Vet Rec 139:348-349

Roubal FR, Lester RJG, Foster CK (1989) Studies on cultured and gill-attached Paramoeba sp. (Gymnamoebae, Paramoebidae) and the cyto-pathology of paramoebic gill disease in Atlantic Salmon, Salmo salar L, from Tasmania. J Fish Dis 12:481-492

Tan CK, Nowak BF, Hodson SL (2002) Biofouling as a reservoir of Neoparamoeba pemaquidensis (Page, 1970), the causative agent of amoebic gill disease in Atlantic salmon. Aquaculture 210:1-4

Vincent BN, Adams MB, Crosbie PBB, Nowak BF, Morrison RN (2007) Atlantic salmon (Salmo salar L.) exposed to cultured gill-derived Neoparamoeba branchiphila fail to develop amoebic gill disease (AGD). Bull Eur Assoc Fish Pathol 27(3):112-115

Wong FYK, Carson J, Elliott NG (2004) 18S ribosomal DNAbased PCR identification of Neoparamoeba pemaquidensis, the agent of amoebic gill disease in sea-farmed salmonids. Dis Aquat Org 60:65-76

Yee A, Dungan C, Hamilton R, Goedken M, De Guise S, Sunila I (2005) Apoptosis of the protozoan oyster pathogen Perkinsus marinus in vivo and in vitro in the Chesapeake Bay and the Long Island Sound. J Shellfish Res 24: 1035-1042

Young ND, Crosbie PBB, Adams MB, Nowak BF, Morrison RN (2007) Neoparamoeba perurans n. sp., an agent of amoebic gill disease of Atlantic salmon (Salmo salar). Int J Parasitol 37:1469-1481

Zilberg D (2005) Amoebic gill disease of marine fish caused by Neoparamoeba pemaquidensis. Acta Zool Sin 51: $554-556$

Submitted: May 10, 2007; Accepted: September 7, 2007

Proofs received from author(s): December 23, 2007
Editorial responsibility: Robin Overstreet, Ocean Springs, Mississippi, USA 